\title{
Effect of temperature and light on the mycelial growth of Gyromitra esculenta in pure culture
}

\author{
MARJATTA RAUDASKOSKI, KALEVI POHJOLA and IRMELI SAARVANTO
}

\begin{abstract}
RAUDASKOSKI, M., POHJOLA, K. and SAARVANTO, I. 1976: Effect of temperature and light on the mycelial growth of Gyromitra esculenta in pure culture. - Karstenia 16: 1 - 5.

The mycelial growth of Gyromitra esculenta (Pers.) Fr. was studied on four different culture media, complete medium, Hagem's medium, minimal medium and Czapek's medium. The mycelium was found to grow best on complete medium. One strain was subsequently cultured on complete medium at temperatures ranging from 6 to $27^{\circ} \mathrm{C}$. The optimum temperature for mycelial growth was $15-23^{\circ} \mathrm{C}$. At $25^{\circ} \mathrm{C}$ and $27^{\circ} \mathrm{C}$ the vegetative growth was slower and some morphological changes were observed in the mycelium.

The mycelium started to grow within 24 hours after cold treatment of one, two and three weeks at $-4^{\circ} \mathrm{C}$. After cold treatment of one, two and three weeks at $-15^{\circ} \mathrm{C}$ and $-25^{\circ} \mathrm{C}$, no growth was observed within 24 hours. At $-15^{\circ} \mathrm{C}$ the duration of the cold treatment was significant for the recovery of the mycelium; it clearly grew better after one than two or three weeks in cold. The same tendency was observable after cold treatment at $-25^{\circ} \mathrm{C}$.
\end{abstract}

M. Raudaskoski, K. Pobjola and I. Saarvanto, Department of Botany, Institute of Biology, University of Turku, SF-20500 Turku 50, Finland.

During the last few years in Finland, considerable attention has been paid to the possibility of activating the mycelium of the morel Gyromitra esculenta (Pers.) Fr. to produce fruitbodies, either in pure culture in the laboratory or in its natural environment, by modifying the external conditions (Jalkanen 1973). A better understanding of the conditions essential to fruitbody production has been sought by measuring different environmental factors, such as temperature and the $\mathrm{pH}$ and mineral content of the soil in the habitats of $G$. esculenta (Pohjola, unpublished data). At the same time, the nutrients, temperature and light required for optimum growth of the mycelium have been studied in the laboratory. The present paper describes the results of the laboratory experiments and examines them from the point of the view of the possible initiation of fruitbody production.

\section{Materials and methods}

Fruitbodies of $G$. esculenta were collected from pine wood in Kuttura, Inari parish in North Finland (lat. $68^{\circ} 17^{\prime} \mathrm{N}$ and long. $27^{\circ} 8^{\prime} \mathrm{E}$ ) in July 1970 . The fruitbodies were dried and stored in paper bags at room temperature. Spores were isolated by squeezing a piece of dried fruitbody in distilled water, and $0.5 \mathrm{ml}$ of the solution was pipetted on to Hagem's agar in Petri dishes and spread with an L-shaped glass rod. The spore cultures were kept for one day at room temperature, after which $100 \%$ germination was observed under a dissecting microscope. Single germinated spores were isolated by pressing a sterile micropipette in to the agar and cutting out a circular block of agar with one spore. The block was transferred with a sterile needle to clean culture medium for further growth. Several monosporous strains were isolated by this method and stored in small bottles with complete agar at $5^{\circ} \mathrm{C}$. Two of these strains, 8 and 18 , were used in the experiments.

In the study of the effect of different culture media, temperatures and light on mycelial growth, cellophane membranes were placed over culture medium in Petri dishes. The membrane prevents the penetration of the mycelium into the medium but allows the nutrients to reach the mycelium. Pieces of agar with hyphae were cut with a micropipette from the edge of a well-growing mycelium and transferred with a needle to the middle of the cellophane membranes. By this technique inocula of the same size and type were transferred to five replicate Petri dishes for each experiment. The mycelium was grown for ten days, after which it was harvested from the membranes with a razor blade and dried at $55^{\circ} \mathrm{C}$ for 24 hours.

In the study of the effect of cold the inocula were placed directly on the agar. A check was made for possible growth in the cold by measuring the diameters of the mycelial colonies with a ruler immediately before and after the cold treatment. The recovery of the mycelium from the cold treatment was followed by measuring the 
diameters of the colonies after one and seven days' growth at $20^{\circ} \mathrm{C}$ in an 18 -hr photoperiod. Three replicate Petri dishes were used for each experiment.

\section{Results}

The composition of the four media tested for suitability for the growth of the mycelium of $G$. esculenta is given in Table 1. On each medium mycelium of strain 8 was grown at three different temperatures, $15^{\circ} \mathrm{C}, 20^{\circ} \mathrm{C}$ and $25^{\circ} \mathrm{C}$, and at each temperature three different types of illumination were used: continuous light, rhythmic light and darkness. The rhythmic light consisted of 18 hours of light and 6 hours of darkness, and the light intensity was 2500-3000 lux in both continuous and rhythmic light. The mycelium grew best on complete medium in all temperature and light conditions (Table 2). The dry weights of the mycelium on complete medium were smallest at $25^{\circ} \mathrm{C}$ in all types of illumination. On Hagem's and Czapek's media, the dry weights of the mycelium were small. The poorest yield of mycelium was obtained from minimal medium, especially at $15^{\circ} \mathrm{C}$, in all types of illumination, and at $20^{\circ} \mathrm{C}$ and $25^{\circ} \mathrm{C}$ in continuous light.

The complete medium was chosen for a more detailed investigation of the effect of temperature and light on mycelial growth. Strain 18 was used in this experiment, and a broader range of temperatures was tested, while the illumination and light intensity were kept the same as in the previous experiment. Table 3 presents the data of the experiment and the results of the analysis of variance applied to the data. At $6^{\circ} \mathrm{C}$ mycelial growth was sufficiently great to be measured by weighing. At $15^{\circ} \mathrm{C}$ the dry weights of the mycelium were significantly greater than at $6^{\circ} \mathrm{C}$, and they remained at this level at $20^{\circ} \mathrm{C}$ and $23^{\circ} \mathrm{C}$. At $25^{\circ} \mathrm{C}$ and $27^{\circ} \mathrm{C}$ the dry weights were significantly lower than at the three preceding temperatures.

Illumination had no effect on the dry weights of the mycelium at the optimum temperatures $15^{\circ} \mathrm{C}, 20^{\circ} \mathrm{C}$ and $23^{\circ} \mathrm{C}$ (Table 3). At $12^{\circ} \mathrm{C}$ the dry weights of mycelium grown in continuous light were higher than those of mycelium in rhythmic light and dark. At $27^{\circ} \mathrm{C}$ light had the opposite effect; significantly higher dry weights were obtained from dark cultures than from those in rhythmic and continuous light.

In ten days at $15^{\circ} \mathrm{C}, 20^{\circ} \mathrm{C}$ and $23^{\circ} \mathrm{C}$, the mycelium of G. esculenta spread over the whole surface of the agar in the Petri dish. The mycelium was white with few aerial hyphae, these features being unaffected by illumination. At $25^{\circ} \mathrm{C}$ and $27^{\circ} \mathrm{C}$, mycelial growth was less extensive, and in ten days only half, or less, of the surface of the agar was covered. At the higher temperatures some morphological differences could also be observed in the mycelium. It was more compact and had a greater amount of pigment. These differences were more evident in cultures kept in the light than in the dark.

Strains 8 and 18 were both subjected to cold treatment, being kept at $-4^{\circ} \mathrm{C},-15^{\circ} \mathrm{C}$ and $-25^{\circ} \mathrm{C}$ for one, two and three weeks and then transferred to $20^{\circ} \mathrm{C}$. After one week at $-4^{\circ} \mathrm{C}$, the strains started to grow within 24 hours at $20^{\circ} \mathrm{C}$, but after one week at $-15^{\circ} \mathrm{C}$ and $-25^{\circ} \mathrm{C}$ practically no growth was observed within 24 hours. Cultures kept at $-4^{\circ} \mathrm{C}$ for two and three weeks also started to grow within 24 hours, whereas no growth was observed in this time in cultures kept at $-15^{\circ} \mathrm{C}$ and $-25^{\circ} \mathrm{C}$.

The cultures were measured again after seven days at $20^{\circ} \mathrm{C}$ and the analysis of variance was applied to the results, to examine the effect of different temperatures and periods of cold treatment on the growth rates of the strains (Table 4). The analysis of variance indicated that with all three periods of cold treatment there was a significant difference in growth rates between the cultures of strain 8 kept at $-4^{\circ} \mathrm{C}$ and those kept at $-15^{\circ} \mathrm{C}$ and $-25^{\circ} \mathrm{C}$. The effect of temperature was less clear in the growth rates of strain 18. The only significant difference was that found after cold treatment of two weeks between the cultures kept at $-4^{\circ} \mathrm{C}$ and those kept at $-15^{\circ} \mathrm{C}$ and $-25^{\circ} \mathrm{C}$. In strain 8 , the growth rates of the cultures kept at $-4^{\circ} \mathrm{C}$ one and three weeks, and in strain 18 the growth rates of all the cultures kept at $-4^{\circ} \mathrm{C}$ were unaffected by the duration of the cold treatment (Table 4). In contrast, the growth rates of the cultures kept at $-15^{\circ} \mathrm{C}$ were significantly lower after two and three weeks than after one, and a similar tendency was evident in the cultures kept at $-25^{\circ} \mathrm{C}$, although the differences were not significant in strain 18 .

\section{Discussion}

Most of the macrofungi studied for their nutrient, temperature, and light requirements in pure culture belong to the basidiomycetes (cf. Volz \& Beneke 1969). Less attention has been paid to the requirements of ascomycetous macrofungi, apart from research on the mycelial growth of Morchella species (Litchfield \& Overbeck 1963, Litchfield et al. 1963, Litchfield 1964). In the present study the purpose was not to develop a special medium for the growth and fruitbody formation of G. esculenta, but to find a defined medium on which the growth of the mycelium would be sufficient to reveal changes in the yield and morphology induced by different temperatures and light conditions. The growth of the mycelium on complete medium was good enough to fulfil these requirements.

The optimum temperature for the mycelial growth of G. esculenta on complete medium was $15-23^{\circ} \mathrm{C}$. The optimum temperature is in some basidiomycetes occurring in late summer and autumn the same for mycelial growth and fruitbody formation (McLaughlin 1970, Schmaus 1972), while in other species a decrease in temperature is needed to induce or improve fruitbody formation (Aschan 
Table 1. Composition of the tested media.

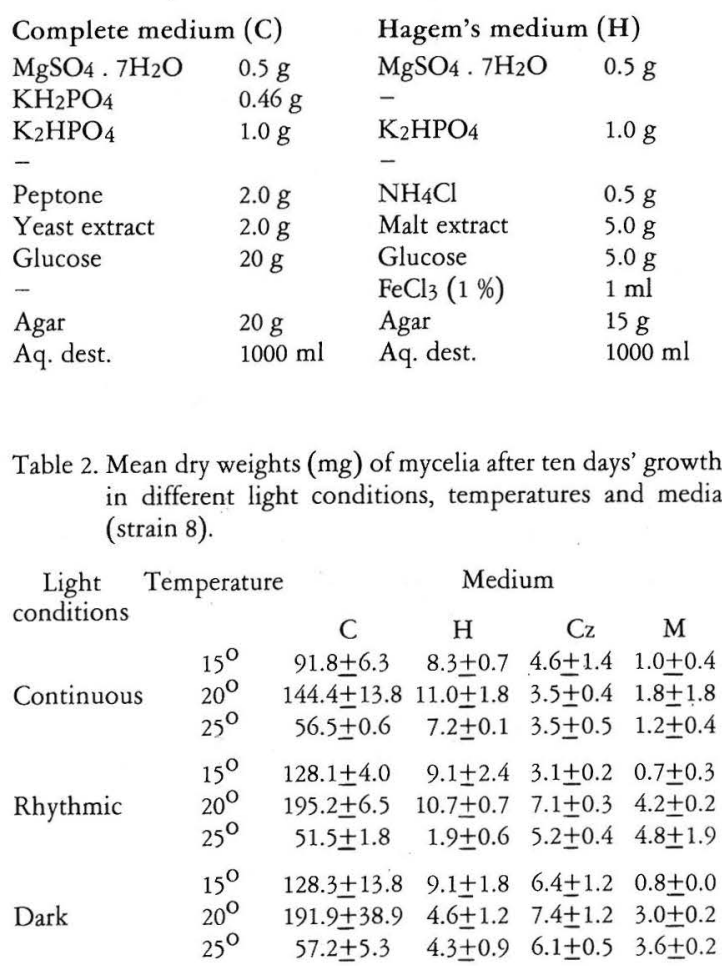

1954, Madelin 1956, Kinugawa \& Furukawa 1965, Ishikawa 1967, Miller 1971, Schmaus 1972). In G. esculenta, which is a spring fungus, an increase in temperature might be necessary for fruitbody formation. This assumption is supported by the observation that at higher temperatures than $23^{\circ} \mathrm{C}$ the vegetative growth of the mycelium slowed down and the pigmentation of the mycelium increased, changes which, at least in some basidiomycetes, precede fruitbody formation.

Light also plays an important role in the formation of fruitbodies in several fungi. Cultures kept in complete darkness failed to form primordia in the basidiomycetes Lentinus edodes (Ishikawa 1967), Tylopilus felleus (McLaughlin 1974), Coprinus lagopus (Madelin 1956, Lu 1974), Funalia gallica (Trametes extenuata, Miller \& Liberta 1972) and Scbizopbyllum commune (Perkins 1969). In Boletus rubinellus primordia were initiated in the dark but the stipes did not develop further (McLaughlin 1970), while in Collybia velutipes the pilei required light for expansion (Aschan 1954). In the ascomycetes Sclerotinia sclerotiorum (Letham 1975) and Botryotinia squamosa (Bergquist \& Lorbeer 1972) the apothecial initials also develop in the dark but fail to form mature apothecia in continued darkness. Light is

\begin{tabular}{llll}
\multicolumn{2}{l}{ Minimal medium (M) } & \multicolumn{2}{l}{ Czapek's medium $(\mathrm{Cz})$} \\
$\mathrm{MgSO}_{4} \cdot 7 \mathrm{H}_{2} \mathrm{O}$ & $0.5 \mathrm{~g}$ & $\mathrm{MgSO}_{4} \cdot 7 \mathrm{H}_{2} \mathrm{O}$ & $0.5 \mathrm{~g}$ \\
$\mathrm{KH}_{2} \mathrm{PO}_{4}$ & $0.46 \mathrm{~g}$ & - & \\
$\mathrm{K}_{2} \mathrm{HPO}_{4}$ & $1.0 \mathrm{~g}$ & $\mathrm{~K}_{2} \mathrm{HPO}_{4}$ & $1.0 \mathrm{~g}$ \\
- & & $\mathrm{KCl}$ & $0.5 \mathrm{~g}$ \\
Asparagine & $1.0 \mathrm{~g}$ & $\mathrm{NaNO}_{3}$ & $3.0 \mathrm{~g}$ \\
- & & - & \\
Glucose & $20 \mathrm{~g}$ & Sucrose & $30 \mathrm{~g}$ \\
Thiamine- $\mathrm{HCl}$ & $60 \mu \mathrm{g}$ & FeSO $4.7 \mathrm{H}_{2} \mathrm{O}$ & $0.01 \mathrm{~g}$ \\
Agar & $20 \mathrm{~g}$ & Agar & $15 \mathrm{~g}$ \\
Aq. dest. & $1000 \mathrm{ml}$ & Aq. dest. & $1000 \mathrm{ml}$ \\
& & &
\end{tabular}

considered unnecessary for the fruitbody formation of Agaricus bisporus (Koch 1958), but in L. edodes (Ishikawa 1967) very low light intensities can induce fruitbody formation. In G. esculenta light enhanced the effect of high temperatures, so that at such temperatures the vegetative growth of the mycelium was poorer in light than in dark. At this phase of our research it is, however, impossible to speculate on the significance of this observation.

Like that of some basidiomycetes (Moser 1958), the mycelium of $G$. esculenta was very resistant to low temperatures and recovered rapidly from cold treatment at $-4^{\circ} \mathrm{C}$. Temperatures around $-4^{\circ} \mathrm{C}$ may be important for fruitbody formation in $G$. esculenta. The mycelium or fruitbody initials may require a period of dormancy at low temperatures before the fruitbody can be developed, as in the ascomycete B. squamosa (Bergquist \& Lorbeer 1972). On the other hand, the mycelium of $G$. esculenta is probably never exposed to such low temperatures as $-15^{\circ} \mathrm{C}$ and $-25^{\circ} \mathrm{C}$ in nature.

In the further study of mycelial growth and differentiation in $G$. esculenta, some new approaches should be considered. Although the mycelium grew well on complete medium, other media should be tried for their suitability in inducing fruitbody formation (Aschan-Åberg 1960). In the present study the mycelia used originated from single spores, but, the formation of fruitbodies might involve a sexual process between mycelia of different origin (Bresinsky et al. 1972). In recent studies on fruitbody formation in ascomycetes (Vigfusson \& Cano 1974, Bergquist \& Lorbeer 1972) and in basidiomycetes (Leonard \& Dick 1968, Uno \& Ishikawa 1971, 1973) good results have been achieved by treating sterile mycelia in pure culture with an extract from fresh fruitbodies of the same species of different species.

Acknowledgements. This work was supported by grants from the Foundation for Natural Resources in Finland (Suomen Luonnonvarain Tutkimussäätiö) and from the Regional Development Found of Finland LDD (Kehitysaluerahasto Oy). 
Table 3. Mean dry weights (mg) of mycelia after ten days' growth on complete medium. Results of analysis of variance and Tukey's test applied to dry weights in different light conditions (right) and different temperatures (below) (strain 18).

\begin{tabular}{|c|c|c|c|c|c|}
\hline Temperature & Continuous light & Rhythmic light & Darkness & $\begin{array}{c}\text { Analysis } \\
\text { of variance } \\
\text { F }\end{array}$ & $\begin{array}{c}\text { Tukey's test } \\
\text { D }\end{array}$ \\
\hline $6^{\mathrm{O}}$ & $2.1 \pm 0.1$ & $1.8 \pm 0.2$ & $1.9 \pm 0.1$ & 1.4 & \\
\hline $12^{\circ}$ & $40.4 \pm 0.4$ & $31.0 \pm 2.6$ & $29.0 \pm 2.2$ & 5.6 * & 8.9 \\
\hline $15^{\circ}$ & $133.4+8.1$ & $128.8 \pm 13.8$ & $105.6 \pm 12.7$ & 1.6 & \\
\hline $20^{\circ}$ & $173.3 \pm 18.8$ & $147.8 \pm 11.49$ & $142.4 \pm 15.2$ & 1.0 & \\
\hline $23^{\circ}$ & $144.8 \pm 12.8$ & $120.7 \pm 2.9$ & $167.6 \pm 11.9$ & 3.4 & \\
\hline $25^{\mathrm{O}}$ & $62.0 \pm 5.5$ & $89.4 \pm 6.2$ & $86.8 \pm 8.4$ & $5.5 *$ & 25.1 \\
\hline $27^{\circ}$ & $15.4 \pm 2.7$ & $13.6 \pm 3.0$ & $38.6 \pm 1.1$ & $32.6 * * *$ & 9.2 \\
\hline al. of variance $I$ & $63.5 * * *$ & $62.2 * * *$ & $43.7 * * *$ & & \\
\hline sey's test & 38.1 & 34.2 & 42.5 & & \\
\hline
\end{tabular}

Table 4. Mean growth measurements $(\mathrm{mm})$ of strains 8 and 18 seven days after cold treatment. Results of analysis of variance and Tukey's test applied to growth rates after exposure to different temperatures (right) and after exposure for different periods (below the means of each strain).

\begin{tabular}{|c|c|c|c|c|c|c|}
\hline Strain & $\begin{array}{c}\text { Time in cold } \\
\text { Weeks }\end{array}$ & -4 & $\begin{array}{c}\text { Temperature } \\
-15\end{array}$ & -25 & $\begin{array}{c}\text { Analysis of variance } \\
\text { F }\end{array}$ & $\begin{array}{c}\text { Tukey's test } \\
\text { D }\end{array}$ \\
\hline \multirow[t]{3}{*}{8} & 1 & $67.5 \pm 0.2$ & $42.3 \pm 0.4$ & $41.7 \pm 1.9$ & $174.8 * * *$ & 4.8 \\
\hline & 2 & $39.8 \pm 0.7$ & $15.8 \pm 2.8$ & $19.0 \pm 5.5$ & $6.8 *$ & 23.9 \\
\hline & 3 & $61.3 \pm 5.5$ & $16.8 \pm 4.3$ & $3.5 \pm 2.5$ & $40.3 * * *$ & 21.9 \\
\hline Anal. of variance $F$ & & 8.8 * & $25.6 * * *$ & $39.0 * * *$ & & \\
\hline Tukey's test $\quad$ D & & 22.1 & 12.9 & 15.9 & & \\
\hline \multirow[t]{3}{*}{18} & 1 & $42.8 \pm 13.9$ & $46.3 \pm 4.8$ & $31.5 \pm 4.3$ & 0.8 & \\
\hline & 2 & $45.7 \pm 5.1$ & $16.2 \pm 1.7$ & $14.0 \pm 6.8$ & $13.0 * * *$ & 23.1 \\
\hline & 3 & $37.8 \pm 16.9$ & $15.0 \pm 0.3$ & $15.5 \pm 7.8$ & 1.5 & \\
\hline
\end{tabular}

Anal. of variance $F$

Tukey's test D
0.1

D

0.1

$41.2 * * *$
12.0

2.3

\section{References}

Aschan, K. 1954: The production of fruit-bodies in Collybia velutipes. I. Influence of different culture conditions. Physiol. Plant. 7: 571-591.

Aschan-Åberg, K. 1960: Studies on mono- and dikaryotic mycelia of Collybia velutipes. - Physiol. Plant. 13: 280-297.

Bergquist, R. P. \& Lorbeer, J. W. 1972: Apothecial production, compatibility and sex in Botryotinia squamosa. - Mycologia 64: 1270-1281.

Bresinsky, A., Glaser, W. \& Stangl, J. 1972: Untersuchungen zur Sippenstruktur der Morchellaceen. - Ber. Bayer. Bot. Ges. 43: 127-143.

Ishikawa, H. 1967: Physiological and ecological studies on Lentinus edodes (Berk.) Sing. - J. Agr. Lab. 8: 1-53.
Jalkanen, E. 1973: Korvasienen tuntemus lisääntyy. - PuutarhaUutiset 25: 582-583.

Kinugawa, K. \& Furukawa, H. 1965: The fruit-body formation in Collybia velutipes induced by the lower temperature treatment of one short duration. - Bot. Mag. Tokyo 78: 240-244.

Koch, W. 1958: Untersuchungen über Mycelwachstum und Fruchtkörperbildung bei einigen Basidiomyceten (Polystictus versicolor, Polyporus annosus, Pleurotus ostreatus und Psalliota bispora). - Arch. Mikrobiol. 30: 409-432.

Leonard, T. J. \& Dick, S. 1968: Chemical induction of haploid fruiting bodies in Schizophyllum commune. - Proc. Nat. Acad. Sci. 59: 745-751. 
Letham, D. B. 1975: Stimulation by light of apothecial initial development of Sclerotinia sclerotiorum. - Trans. Brit. Mycol. Soc. 65: 333-335.

Litchfield, J. H. 1964: The mass cultivation of Morchella species in submerged culture and their potential uses as sources of protein. In: Starr, M. P. (ed.): Global impacts of applied microbiology. - pp. 327-337. New York.

Litchfield, J. H. \& Overbeck, R. C. 1963: Submerged culture growth of Morchella species in food processing waste substrates. - Proc. I Int. Congr. Food. Sçi. Technol. London (B-6) 2: 511-520.

Litchfield, J. H., Overbeck, R. C. \& Davidson, R. S. 1963: Factors affecting the growth of morel mushroom mycelium in submerged culture. - Agric. Food Chem. 11: 158-162.

Lu, B. C. 1974: Meiosis in Coprinus. V. The role of light on basidiocarp initiation, mitosis, and hymenium differentiation in Coprinus lagopus. - Can. J. Bot. 52: 299-305.

Madelin, M. F. 1956: The influence of light and temperature on fruiting of Coprinus lagopus Fr. in pure culture. - Ann. Bot. London 2: 467-480.

McLaughlin, D. J. 1970: Environmental control of fruitbody development in Boletus rubinellus in axenic culture. - Mycologia 62: 307-331.

- -1974: Fruitbody formation by Tylopilus felleus in axenic culture. - Mycologia 66: 197-201.
Miller, R. E. 1971: Evidence of sexuality in the cultivated mushroom, Agaricus bisporus. - Mycologia 63: 630-634.

Miller, R. M. \& Liberta, A. E. 1972: The effects of visible light on fruit-body development in Trametes extenuatus. - Mycologia 64: 924-926.

Moser, M. 1958: Der Einfluss tiefer temperaturen auf das Wachstum und die Lebenstätigkeit höherer Pilze mit spezieller Berücksichtigung von Mykorrhizapilzen. - Sydowia Ann. Myc., Ser. II, 12: 386-399.

Perkins, J. H. 1969: Morphogenesis in Schizophyllum commune. I. Effects of white light. - Plant Physiol. 44: 1706-1711.

Schmaus, F. 1972: Ein neuer Pilz (Pleurotus ostreatus). - Der Champignon 134: 5-11.

Uno, I. \& Ishikawa, T. 1971: Chemical and genetical control of induction of monokaryotic fruiting bodies in Coprinus macrorhizus. - Molec. Gen. Genetics 113: 228-239.

- - 1973: Purification and identification of the fruiting-inducing substances in Coprinus macrorhizus. - J. Bacteriol. 113: 12401248.

Vigfusson, N. V. \& Cano, R. J. 1974: Artificial induction of the sexual cycle of Neurospora crassa. - Nature 249: 383385.

Volz, P. A. \& Beneke, E. S. 1969: Nutritional regulation of basidiocarp formation and mycelial growth of Agaricales. Mycopath. Mycol. Appl. 37: 225-253.

Accepted for publication on

August 31, 1976 